\title{
ANALISIS KERUSAKAN GERBONG DATAR "PPCW"42 TON AKIBAT BEBAN OPERASI
}

\section{FAILURE ANALYSIS OF “PPCW" 42 TON FLAT WAGON UNDER OPERATION LOADS}

\author{
Anwar dan M. Gozali \\ Balai Besar Teknologi Kekuatan Struktur, BPPT \\ Kawasan PUSPIPTEK, Setu, Tangerang Selatan 15314 \\ e-mail: anwar@bpt.go.id dan muchamad.gozali@bppt.go.id
}

\begin{abstract}
Abstrak
Beberapa unit gerbong PPCW kapasitas 42 ton yang digunakan untuk pengangkutan semen, mengalami retak pada bagian rangka bawah. Untuk menegetahui penyebab terjadinya retak tersebut, dilakukan penelitian dengan cara mengukur tegangan yang terjadi pada saat gerbong beroperasi.

Hasil penelitian berupa besaran tegangan rata-rata dan tegangan amplitudo yang diukur secara real-time pada berbagai kondisi jalan, dianalisis dengan menggunakan pendekatan diagram batas lelah. Hasil analisis menunjukkan bahwa tegangan pada beberapa titik berada pada daerah kritis atau diagram garis batas lelah. Hal ini merupakan penyebab terjadinya kerusakan struktur rangka bawah gerbong PPCW.
\end{abstract}

Kata kunci : Gerbong PPCW, tegangan, diagram batas lelah.

Abstract

Several units of PPCW wagons capacity of 42 ton are used for the cement transportation, cracked on the under frame structures. To determine the cause of the cracks, the investigation was conducted by measuring the stress that occurs when the wagons operation.

Results of the investigations are the mean stresses and amplitude stresses measured in real-time in the various road conditions, and then be analyzed using fatigue limit diagram approach to get fatigue strength of the wagon structure. The analysis result shows that the stresses at several points of the wagon structure under the operational loads are in the critical area or is above the fatigue limit diagram. This is the cause of the failure of the under frame of the PPCW wagon structure.

Keyword : PPCW wagon, stresses, fatigue limit diagram.

\section{PENDAhULUAN}

Salah satu moda transportasi darat yang efektif untuk keperluan pemindahan manusia maupun barang adalah kereta api. Kereta api cukup efektif digunakan terutama untuk angkutan masal baik untuk jarak jauh maupun jarak dekat. Terdapat perbedaan antara sarana perkeretaapian yang digunakan untuk pengangkutan manusia dan barang. Sarana perkeretaapian yang digunakan untuk pengangkutan manusia disebut dengan kereta, sedangkan untuk pengangkutan barang disebut gerbong.

Salah satu contoh penggunaan sarana perkeretaapian yang cukup efektif adalah pengangkutan semen dari pabrik yang berlokasi di Cibinong Jawa Barat ke beberapa daerah di Jawa Tengah dan Jawa Timur. Jenis sarana perkeretaapian yang digunakan untuk pengangkutan semen tersebut adalah gerbong PPCW $(P=$ Platte wagen, $C=$ compressed air brake, $W=$ Westinghouse Air Brake Company) yang artinya gerbong datar yang menggunakan roda dengan 4 gandar dengan tipe rem udara bertekanan produksi Westinghouse Air Brake Company.

Pengangkutan semen dengan menggunakan sarana perkeretaapian sangat efektif karena disamping kapasitasnya yang besar, juga terbebas dari kemacetan yang umum terjadi di jalan raya, sehingga waktu tempuh menjadi lebih cepat.

Gerbong PPCW adalah salah satu jenis gerbong datar, yaitu gerbong yang hanya berupa lantai tanpa dilengkapi badan dan atap. Gerbong jenis ini biasanya digunakan untuk pengangkutan peti kemas (container). Namun untuk pengangkutan semen dengan menggunakan peti kemas, menjadi masalah karena waktu yang 
diperlukan untuk bongkar muat sangat lama dan memerlukan peralatan angkut yang rumit. Untuk mempermudah proses bongkar muat, maka pengguna tidak menggunakan peti kemas sebagai tempat semen, namun semen langsung ditempatkan dengan cara menyusun di atas lantai gerbong datar, kemudian diikat dengan menggunakan tali pada rangka samping gerbong.

Akibat dari perubahan fungsi dari gerbong datar yang semestinya menggunakan peti kemas, namun dalam pelaksanaannya tidak menggunakan peti kemas, maka berakibat terjadinya beberapa gerbong yang mengalami retak. Perubahan tersebut sangat berpengaruh terhadap distribusi beban yang diterima oleh struktur gerbong. Jika menggunakan peti kemas, distribusi beban terjadi pada beberapa titik yaitu di titik kontak antara kaki peti kemas dengan lantai gerbong. Sedangkan jika tidak menggunakan peti kemas, maka distribusi beban adalah berupa beban merata sepanjang lantai gerbong.

Perubahan distribusi beban akan berpengaruh terhadap distribusi tegangan pada struktur gerbong. Hal ini merupakan hipotesa awal dari terjadinya retak pada struktur rangka bawah gerbong PPCW. Untuk membuktikan hipotesa tersebut serta mengetahui seberapa besar perubahannya, dilakukan penelitian.

Penelitian dilakukan dengan cara melakukan uji dinamis untuk mengetahui kondisi peralatan dan kemampuan kerja gerbong pada keadaan bergerak/ beroperasi $^{(1)}$. Kemudian dilakukan pengukuran regangan/tegangan yang terjadi pada saat gerbong PPCW beroperasi. Hasil pengukuran dianalisis terhadap perilaku lelah dari material sehingga dapat diketahui apakah struktur tersebut aman atau tidak jika dioperasikan.

\section{- BAHAN DAN METODE}

\subsection{Gerbong PPCW}

Berdasarkan peraturan menteri Perhubungan No. 43 Tahun 2010, sarana perkeretaapian yang ditarik oleh lokomotif dan digunakan untuk pengangkutan barang disebut dengan istilah gerbong ${ }^{(2)}$.

Dalam peraturan tersebut, gerbong dibagi menjadi 4 jenis, yaitu : gerbong datar, gerbong terbuka, gerbong tertutup, dan gerbong tangki.

Gerbong datar PPCW adalah gerbong yang hanya terdiri dari struktur rangka bawah yang ditopang oleh bogie, dilengkapi dengan lantai tanpa dilengkapi dinding (badan) dan atap. Gerbong PPCW dirancang untuk digunakan dalam pengangkutan peti kemas, baja koil, baja billet, baja pelat, kayu balok, pipa besi, dan lain-lain.

Sebagai obyek pada penelitian ini adalah gerbong datar PPCW (foto gerbong datar PPCW ditampilkan pada gambar 1) yang digunakan untuk pengangkutan semen di pulau Jawa, yaitu dari pabrik semen yang berlokasi di Cibinong Jawa Barat ke beberapa daerah di Jawa Tengah dan Jawa Timur.

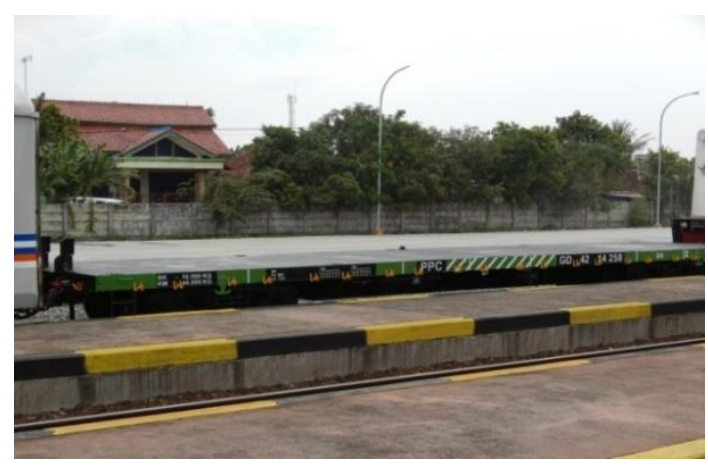

Gambar 1 : Gerbong PPCW sebagai obyek penelitian.

Spesifikasi dari gerbong PPCW adalah sebagai berikut : kapasitas 42 ton, kecepatan max. $80 \mathrm{~km} / \mathrm{jam}$, lebar sepur $1067 \mathrm{~mm}$, beban gandar 14 ton, panjang rangka dasar $14600 \mathrm{~mm}$, lebar gerbong $2438 \mathrm{~mm}$, tinggi lantai dari rel $935 \mathrm{~mm}$, tinggi alat perangkai $775 \mathrm{~mm}$, berat kosong $(\max ): 12000 \mathrm{~kg}^{(3)}$.

Struktur rangka bawah merupakan bagian utama dari struktur gerbong PPCW, dibuat dari bahan baja SS 400 JIS G $3101^{\left({ }^{3}\right)}$ dengan spesifikasi sebagai berikut : tegangan ultimate $\sigma_{\text {ult }}=400-510 \mathrm{MPa}$, tegangan yiled $\sigma_{0.2}=205-245 \mathrm{MPa}$, modulus elastisitas $E=210000 \mathrm{MPa}$, komposisi kimia : $\mathrm{P}<0,05 \%, \mathrm{~S}<0,05 \%{ }^{(4)}$.

\subsection{Metode}

Permasalahan pada kasus ini adalah terjadinya retak pada struktur rangka bawah dari gerbong PPCW yang digunakan untuk pengangkutan semen. Hipotesa awal seperti diuraikan dalam pendahuluan di atas, adalah keretakan terjadi karena terjadinya perubahan distribusi beban akibat dari perubahan penggunaan gerbong PPCW. 
Untuk membuktikan hipotesa di atas, dilakukan dengan mengukur regangan pada struktur rangka bawah gerbong PPCW. Pengukuran dilakukan pada gerbong PPCW yang tidak mengalami retak sehingga tidak ada pengaruh retakan terhadap regangan. Lokasi titik ukur ditetapkan pada daerah yang mengalami retak serta beberapa titik pada struktur utama rangka bawah, lihat gambar 2.

Sebagai sensor ukur digunakan strain gauge TML tipe FLA 6 - 11. Sedangkan sebagai alat perekam adalah alat ukur dinamis 64 channel $^{(5)}$. Strain gauge dipasang pada titik yang akan diukur regangannya dengan cara dilekatkan (gambar 3), sehingga jika terjadi perpanjangan (regangan) pada titik yang diukur, maka strain gauge akan ikut meregang dan mengeluarkan sinyal berupa voltage. Besaran voltage dikalibrasi terhadap satuan regangan. Keluaran dari strain gauge direkam dengan menggunakan alat ukur dinamis secara real-time.

Pengukuran regangan dilakukan pada saat gerbong beroperasi (lihat gambar 4) dengan kondisi sebagai berikut : beban muatan 40 ton, jenis muatan semen,

posisi beban merata, rute Arjawinangun Purwokerto.

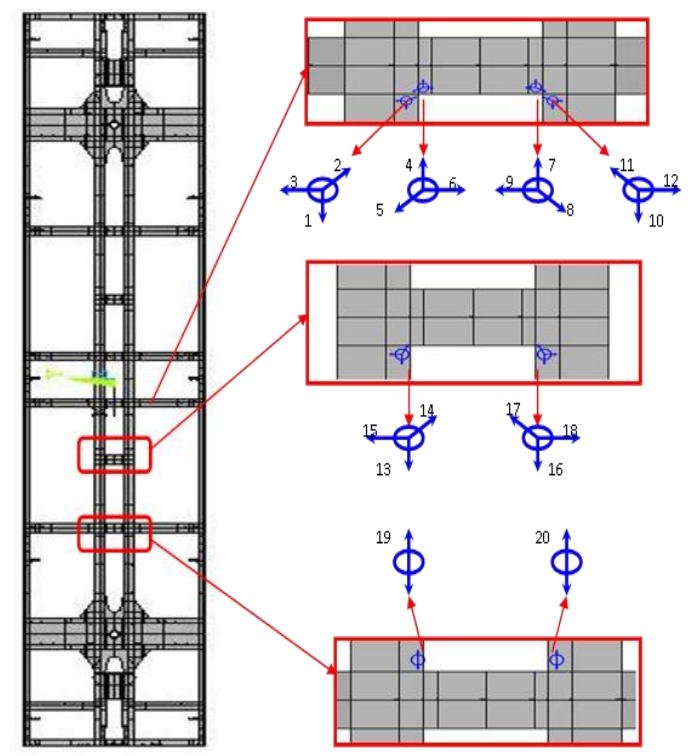

Gambar 2 : Lokasi titik ukur regangan

Pengukuran regangan dilakukan secara real-time pada saat gerbong beroperasi dengan kondisi seperti gambar 5 . Mengingat kapasitas dari alat ukur, pengukuran tidak dilakukan secara terus menerus sepanjang rute perjalanan di atas, namun dilakukan pada beberapa kondisi yang dinilai kritis, yaitu : saat perpindahan rel, tikungan, percepatan, perlambatan / pengereman, kecepatan maksimum, tanjakan, turunan dan jembatan.

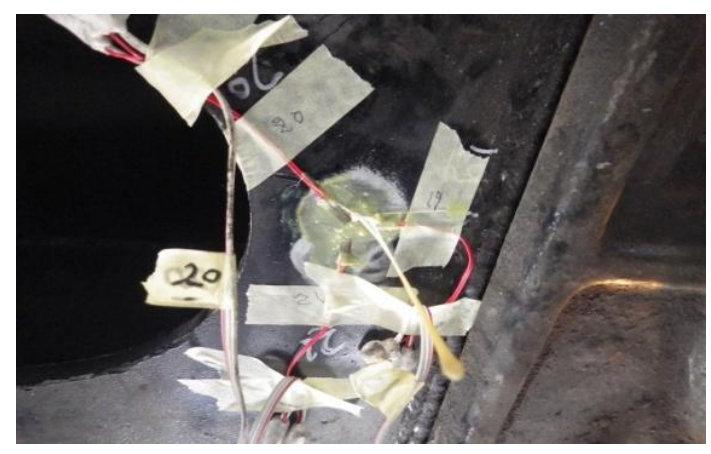

Gambar 3 : Strain gauge yang telah terpasang pada struktur gerbong

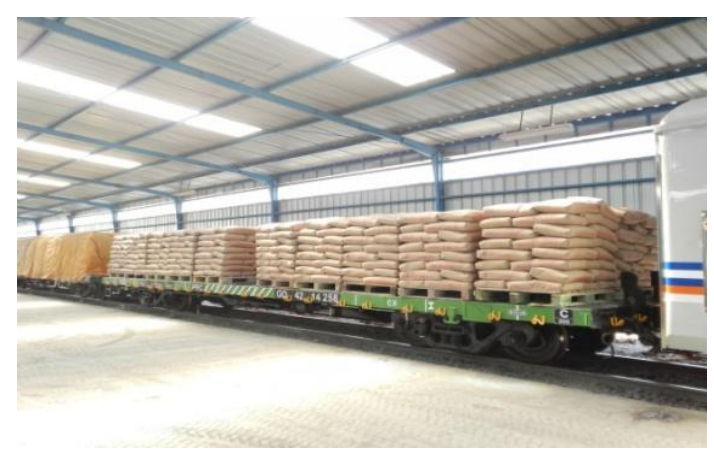

Gambar 4 : Gerbong PPCW yang telah terisi semen, sebelum ditutup terpal.

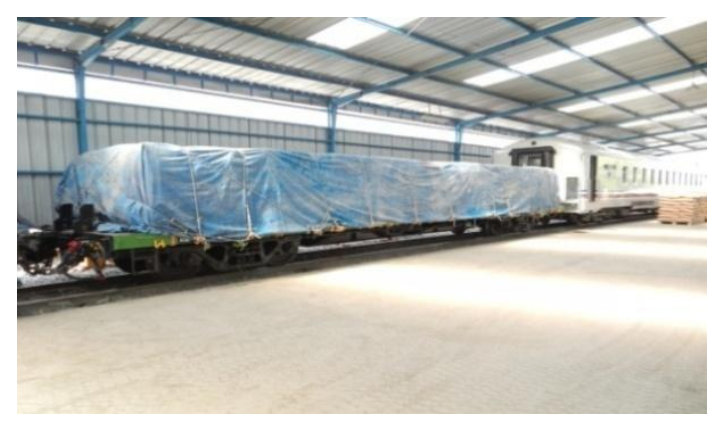

Gambar 5 : Gerbong PPCW yang telah terisi semen, siap uji jalan, setelah ditutup terpal

Hasil pengukuran berupa besaran regangan dikonversi menjadi besaran tegangan. Nilai tegangan terutama tegangan amplitudo dan tegangan rata-rata, digunakan sebagai bahan evaluasi kekuatan lelah untuk mengetahui apakah tegangan yang terjadi berada pada daerah aman atau daerah yang memungkinkan terjadinya kerusakan lelah. Metode evaluasi adalah 
dengan menggunakan pendekatan diagram batas lelah (fatigue limit diagram).

\section{HASIL DAN PEMBAHASAN}

Hasil pengujian berupa data regangan yang direkam secara real-time seperti ditunjukkan pada gambar 6. Gambar 6 menunjukkan contoh hasil pengukuran regangan pada kondisi jalan turun dan berbelok ke kanan. Berdasarkan data rekaman regangan tersebut, ditentukan besaran regangan maksimum, regangan minimum, regangan amplitudo, dan regangan rata-rata.

Data yang diperlukan untuk menganalisis kekuatan lelah adalah besaran regangan rata-rata (mean strain) dan regangan amplitudo (amplitude strain). Hubungan antara regangan maksimum $\left(\varepsilon_{\max }\right)$, regangan minimum $\left(\varepsilon_{\min }\right)$, regangan rata-rata $\left(\varepsilon_{\mathrm{m}}\right)$, dan regangan amplitudo $\left(\varepsilon_{\mathrm{a}}\right)$ dinyatakan dengan persamaan sebagai berikut ${ }^{(6)}(7)$ :

Regangan rata-rata :

$\varepsilon m=\frac{\varepsilon \max +\varepsilon m i n}{2}$

Regangan amplitudo :

$\varepsilon a=\frac{\varepsilon \max -\varepsilon \min }{2}$

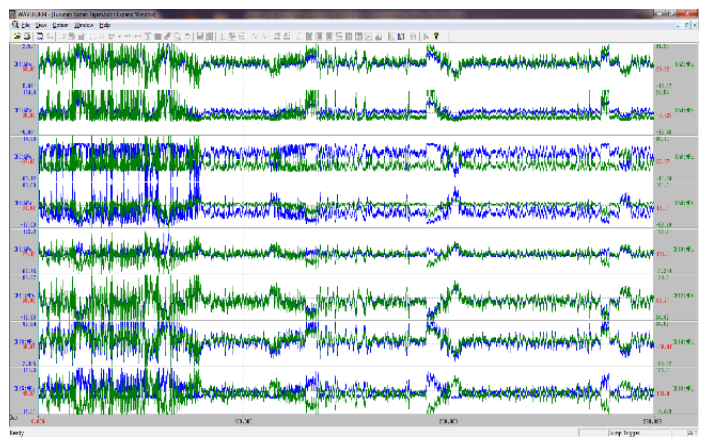

Gambar 6 : Data regangan hasil pengukuran secara real-time pada kondisi jalan turun dan belok ke kanan

Untuk mendapatkan besaran tegangan yang akan digunakan untuk melakukan analisis kelelahan, digunakan
Hukum Hooke sebagai acuan dalam menghitung konversi regangan ke besaran tegangan.

Hubungan antara regangan dan tegangan sesuai Hukum Hooke adalah ${ }^{(8)}$ :

- Strain single : $\sigma=\varepsilon E$

Dimana : $\sigma=$ tegangan $\left(\mathrm{N} / \mathrm{mm}^{2}\right)$.

$$
\begin{aligned}
& \varepsilon=\text { regangan }(\mu \mathrm{m} / \mathrm{m}) . \\
& E=\text { modulus elastisitas }\left(\mathrm{N} / \mathrm{mm}^{2}\right) .
\end{aligned}
$$

- Strain gauge rosette $45^{\circ} / 90^{\circ(8)}$ :

$\sigma_{1,2}=\frac{\mathrm{E}}{2}\left[\left(\frac{\varepsilon_{\mathrm{a}}+\varepsilon_{\mathrm{c}}}{1-v}\right) \pm \frac{\sqrt{2}}{1+v} \sqrt{\left(\varepsilon_{\mathrm{a}}-\varepsilon_{\mathrm{b}}\right)^{2}+\left(\varepsilon_{\mathrm{b}}-\varepsilon_{\mathrm{c}}\right)^{2}}\right]$

-....(4)

Dimana:

$\sigma_{1,2} \quad=$ tegangan utama dengan arah $\sigma_{1}$

dan $\sigma_{2}$ adalah $90^{\circ}\left(\mathrm{N} / \mathrm{mm}^{2}\right)$.

$E \quad=$ modulus elastisitas $\left(\mathrm{N} / \mathrm{mm}^{2}\right)$.

$v \quad=$ Poison's ratio

$\varepsilon_{a} \quad=$ regangan dengan arah $90^{\circ}$ terhadap $\varepsilon_{c}(\mu \mathrm{m} / \mathrm{m})$.

$\varepsilon_{b} \quad=$ regangan dengan arah $45^{\circ}$ terhadap $\varepsilon_{a}$ dan $\varepsilon_{c}(\mu \mathrm{m} / \mathrm{m})$.

Hasil perhitungan besaran tegangan berdasarkan data regangan hasil pengujian, ditunjukkan pada tabel 1. Pada tabel tersebut disajikan data tegangan rata-rata $\left(\sigma_{\text {mean }}\right)$, dan amplitudo $\left(\sigma_{\text {amp }}\right)$.

Tabel 1 hanya merupakan sebagian data yang berisi data pengukuran pada beberapa kondisi jalan yang diolah dengan PcWaveForm ${ }^{(9)}$. Sedangkan data lengkap hasil evaluasi pada berbagai kondisi jalan disajikan pada plot data tegangan pada diagram batas lelah seperti terlihat pada gambar 8 - 13 .

Salah satu metode analisis kelelahan struktur bahan logam adalah dengan pendekatan diagram batas lelah (fatigue limit diagram). Diagram batas lelah adalah diagram yang menggambarkan hubungan antara tegangan rata-rata (mean stress) dan tegangan amplitudo, seperti ditunjukkan pada gambar 7 . 
Tabel 1. Besaran tegangan rata-rata dan amplitudo pada berbagai kondisi jalan

\begin{tabular}{|c|r|r|r|r|r|r|r|r|r|r|}
\hline \multirow{3}{*}{$\begin{array}{c}\text { Strain } \\
\text { Gauge }\end{array}$} & \multicolumn{9}{|c|}{ Jalan lurus } & \multicolumn{10}{|c|}{$\begin{array}{c}\text { Tanjakan belok } \\
\text { kanan }\end{array}$} & \multicolumn{2}{c|}{$\begin{array}{c}\text { Belok kiri } \\
\text { tanjakan }\end{array}$} & \multicolumn{2}{c|}{$\begin{array}{c}\text { Turunan belok } \\
\text { kanan }\end{array}$} & \multicolumn{3}{c|}{ Jembatan } \\
\cline { 2 - 12 } & $\begin{array}{c}\sigma_{\text {mean }} \\
(\mathrm{MPa})\end{array}$ & $\begin{array}{c}\sigma_{\mathrm{amp}} \\
(\mathrm{MPa})\end{array}$ & $\begin{array}{c}\sigma_{\text {mean }} \\
(\mathrm{MPa})\end{array}$ & $\begin{array}{c}\sigma_{\text {amp }} \\
(\mathrm{MPa})\end{array}$ & $\begin{array}{c}\sigma_{\text {mean }} \\
(\mathrm{MPa})\end{array}$ & $\begin{array}{c}\sigma_{\text {amp }} \\
(\mathrm{MPa})\end{array}$ & $\begin{array}{c}\sigma_{\text {mean }} \\
(\mathrm{MPa})\end{array}$ & $\begin{array}{c}\sigma_{\text {amp }} \\
(\mathrm{MPa})\end{array}$ & $\begin{array}{c}\sigma_{\text {mean }} \\
(\mathrm{MPa})\end{array}$ & $\begin{array}{c}\sigma_{\text {amp }} \\
(\mathrm{MPa})\end{array}$ \\
\hline Rosette-1 & 77,9 & 126,0 & 97,2 & 118,7 & 99,9 & 144,1 & 101,5 & 156,0 & 100,1 & 110,9 \\
\hline Rosette-2 & 27,1 & 77,3 & 26,8 & 74,5 & 24,9 & 110,5 & 26,7 & 111,6 & 24,9 & 99,9 \\
\hline Rosette-3 & 23,1 & 85,9 & 21,9 & 74,1 & 19,5 & 120,3 & 21,0 & 119,8 & 21,0 & 93,6 \\
\hline Rosette-4 & 72,4 & 104,0 & 72,3 & 118,7 & 73,5 & 138,7 & 73,6 & 138,7 & 69,6 & 115,5 \\
\hline Rosette-5 & 57,9 & 92,9 & 63,2 & 86,4 & 59,7 & 125,4 & 60,2 & 126,4 & 61,7 & 98,9 \\
\hline Rosette-6 & 73,4 & 140,4 & 68,2 & 152,1 & 70,9 & 177,2 & 71,5 & 179,8 & 65,7 & 161,6 \\
\hline Single 1 & 43,6 & 114,4 & 39,0 & 113,3 & 41,2 & 125,2 & 41,7 & 146,4 & 37,5 & 92,3 \\
\hline Single 2 & 30,0 & 102,8 & 33,1 & 108,7 & 30,6 & 120,1 & 30,0 & 143,7 & 32,4 & 87,4 \\
\hline
\end{tabular}

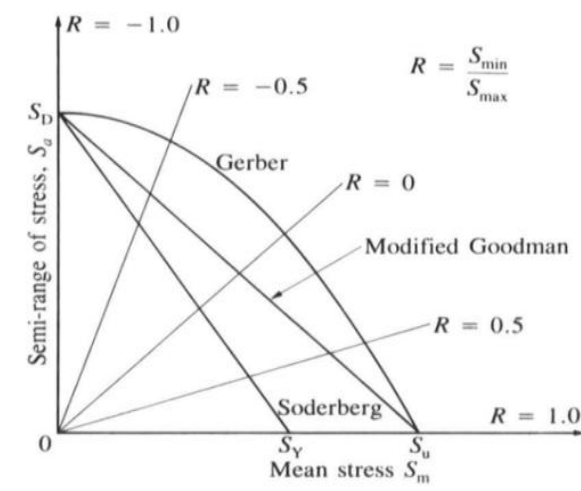

Gambar 7 : Diagram batas lelah (fatigue limit diagram) ${ }^{(10)}$

Ada dua kondisi kritis hubungan antara tegangan rata-rata dengan tegangan amplitudo. Kondisi pertama adalah jika tegangan amplitudo nol, hal ini berarti tegangan rata-rata sama dengan tegangan statis, menurut Gerber dan Goodman kondisi ini diartikan dengan tegangan maksimum (ultimate stress), sedangkan menurut Soderberg kondisi ini diartikan dengan tegangan luluh (yield stress).

Kondisi kedua adalah keadaan dimana tegangan rata-rata sama dengan nol atau beban dinamis dengan perbandingan tegangan $R=-1$. Pada kondisi ini tegangan amplitudo adalah sama dengan tegangan maksimum. Pada kondisi ini Gerber, Goodman, dan Soderberg, sepakat bahwa titik kritis dapat didekati dengan tegangan batas lelah (fatigue limit) yang dinyatakan dengan tegangan endurance, lihat gambar 7.

Berdasarkan kedua kondisi di atas, maka disusunlah hubungan antara tegangan amplitudo dan tegangan rata-rata seperti berikut ${ }^{(10)}$ :

$$
\begin{aligned}
& \text { Gerber } \quad: S a=S D\left[1-\left(\frac{S m}{S u}\right)^{2}\right] \\
& \text { Goodman } \quad: S a=S D\left[1-\frac{S m}{S u}\right] \quad \ldots . . .(6) \\
& \text { Soderberg }: S a=S D\left[1-\frac{S m}{s y}\right]
\end{aligned}
$$

Dimana:

$S_{a}=$ tegangan amplitude $\left(\mathrm{N} / \mathrm{mm}^{2}\right)$

$S_{D}=$ tegangan endurance $\left(\mathrm{N} / \mathrm{mm}^{2}\right)$

$S_{m}=$ tegangan rata-rata $\left(\mathrm{N} / \mathrm{mm}^{2}\right)$

$S_{u}=$ tegangan ultimate $\left(\mathrm{N} / \mathrm{mm}^{2}\right)$

$S_{y}=$ tegangan yield $\left(\mathrm{N} / \mathrm{mm}^{2}\right)$

Struktur dikatakan aman terhadap kerusakan akibat beban dinamis (fatigue failure) apabila kombinasi tegangan ratarata (mean stress) dan tegangan amplitudo (amplitude stress) yang terjadi akibat beban kerja, berada di bawah garis batas lelah. Sedangkan jika tegangan yang terjadi berada di atas garis batas lelah, maka struktur akan mengalami kerusakan akibat beban dinamis atau rusak lelah (fatigue failure).

Data hasil evaluasi berupa nilai tegangan rata-rata $\left(\sigma_{\text {mean }}\right)$, dan tegangan amplitudo $\left(\sigma_{\mathrm{amp}}\right)$, diplot terhadap diagram batas lelah dari material SS 400 JIS G 3101, seperti diperlihatkan pada gambar 8 -13. Gambar 8-13 adalah kondisi jalan yang menggambarkan dan mewakili kondisi jalan kereta yang ada di pulau Jawa khususnya di antara Arjawinangun hingga Purwokerto. 


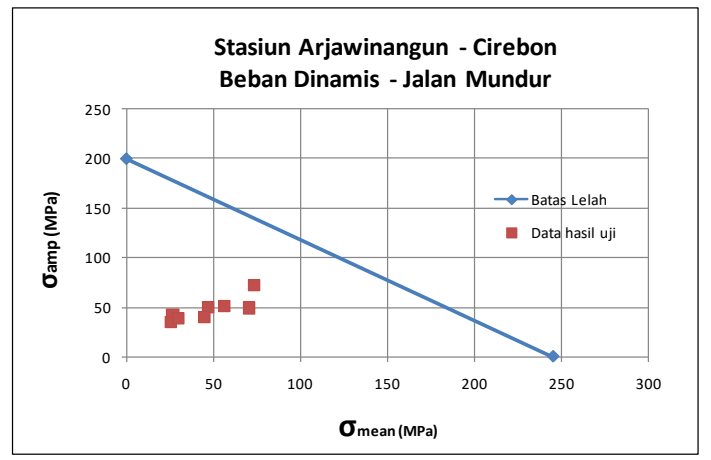

Gambar 8 : Evaluasi tegangan pada kondisi langsir di Arjawinangun.

Gambar 8 menunjukkan hasil evaluasi tegangan rata-rata dan tegangan amplitudo terhadap diagram batas lelah pada kondisi kereta dalam keadaan langsir di stasiun Arjawinangun. Dari gambar tersebut terlihat bahwa semua data tegangan berada di bawah garis batas lelah menurut Soderberg. Hal ini mengindikasikan bahwa untuk kondisi langsir, struktur gerbong cukup aman.

Pada kondisi jalan lurus dengan kecepatan maksimum (70 - $80 \mathrm{~km} / \mathrm{jam})$ seperti ditunjukkan pada gambar 9, dan kondisi di atas jembatan (gambar 10) diperoleh bahwa terdapat satu tegangan yang berada pada garis batas lelah yaitu titik ukur Rosette 6. Hal ini menunjukkan bahwa lokasi titik tersebut diprediksi akan mengalami kerusakan akiabat beban dinamis (fatigue failure).

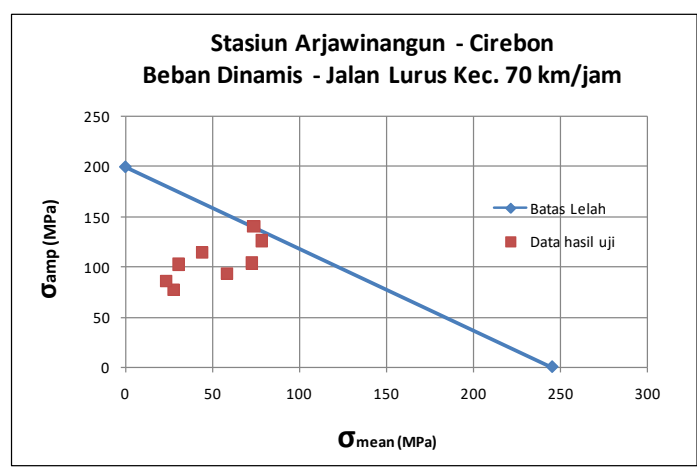

Gambar 9 : Evaluasi tegangan pada kondisi jalan lurus kecepatan maksimum.

Kondisi paling kritis yaitu pada kondisi jalan tanjakan dan turunan disertai dengan belokan seperti ditunjukkan pada gambar 11 dan 12. Pada kondisi tersebut, terdapat tiga yang berada pada daerah lelah yaitu titik ukur Rosette 1, 4, dan 6. Hal ini menunjukkan bahwa di lokasi tersebut diprediksi akan mengalami kerusakan akibat beban dinamis.

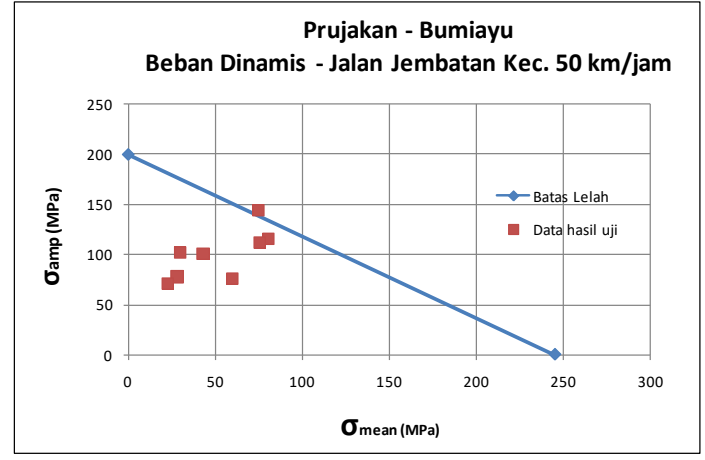

Gambar 10 : Evaluasi tegangan pada kondisi jalan lurus di atas jembatan.

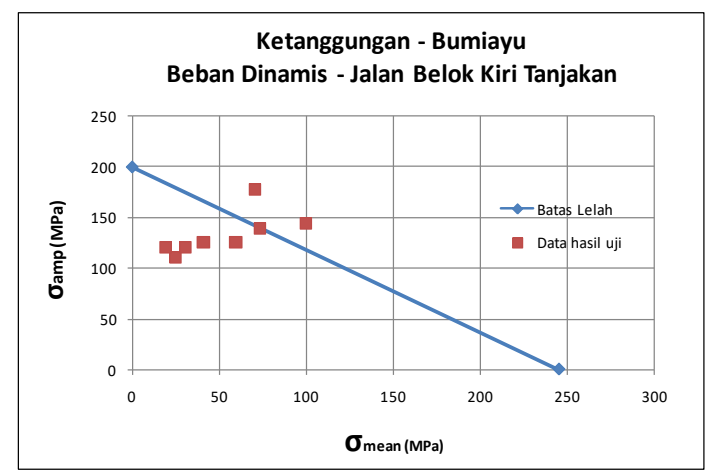

Gambar 11 : Evaluasi tegangan pada kondisi jalan tanjakan dan berbelok.

Sedangkan pada kondisi pengereman yaitu pada saat masuk ke stasiun Purwokerto seperti ditunjukkan pada gambar 13, terlihat bahwa semua titik berada pada daerah aman.

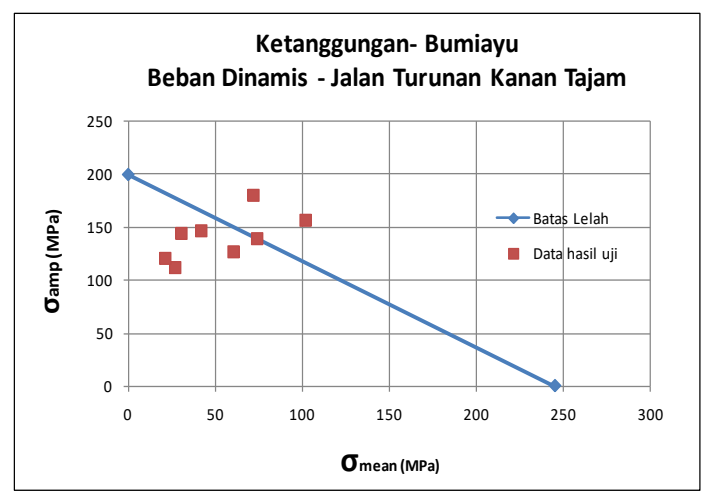

Gambar 12 : Evaluasi tegangan pada kondisi jalan turunan dan berbelok. 


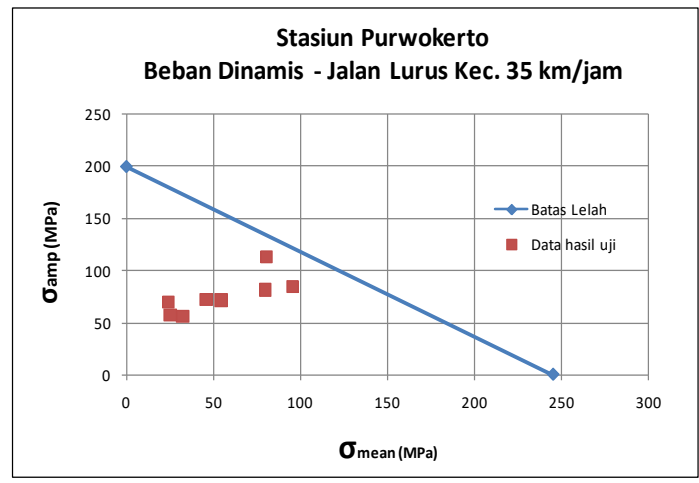

Gambar 13 : Evaluasi tegangan pada kondisi jalan lurus masuk stasiun.

Apabila diperhatikan dari diagram hasil evaluasi di atas, terlihat bahwa tegangan yang dominan menyebabkan kerusakan atau yang menyebabkan tegangan berada di atas batas lelah, adalah tegangan amplitudo. Hasil pengukuran menunjukkan bahwa pada titik kritis, tegangan amplitudo berkisar antara 1,5 hingga 2 kali dari tegangan rata-rata.

Berdasarkan standar UIC 515-4 ${ }^{(4)}$, dinyatakan bahwa beban dinamis adalah 0,3 dari beban statis. Hal ini mengindikasikan bahwa tegangan akibat beban dinamis seharusnya hanya 0,3 dari tegangan akibat beban statis (tegangan rata-rata). Dari hasil pengujian yang menunjukkan nilai tegangan amplitudo sebesar 1,5 hingga 2 kali tegangan rata-rata, maka dapat diartikan bahwa penyebab kerusakan adalah tingginya beban dinamis (tegangan amplitudo).

Penyebab tingginya beban dinamis kemungkinan disebabkan oleh perubahan model beban yang semestinya menggunakan peti kemas (beban terpusat), menjadi beban merata. Selain itu juga dimungkinkan oleh kondisi rel yang tidak rata atau bergelombang. Untuk alasan kedua ini perlu dilakukan penelitian lebih lanjut.

Berdasarkan hasil evaluasi di atas, maka agar gerbong pengangkut semen dapat digunakan dengan aman, ada 2 alternatif yang dapat dilakukan, yaitu : merenovasi atau memperbaiki struktur gerbong, dan mengurangi beban muatan.

Renovasi atau perbaikan struktur gerbong, dimaksudkan untuk meningkatkan kekuatannya sehingga tegangan yang terjadi menjadi lebih kecil dan berada di daerah aman. Perbaikan difokuskan pada lokasi atau titik yang tegangannya berada pada daerah kritis. Model dan bentuk perbaikan perlu diteliti lebih lanjut, yaitu dengan mengetahui arah vektor dari tegangan.

Jika tidak dilakukan perbaikan, struktur gerbong aman digunakan jika beban dikurangi. Dengan mengurangi beban, maka tegangan yang terjadi juga akan turun. Perlu dilakukan penelitian lebih lanjut mengenai hubungan antara tegangan yang terjadi terhadap besarnya beban.

\section{KESIMPULAN DAN SARAN}

Berdasarkan hasil uji dan evaluasi di atas, dapat ditarik beberapa kesimpulan dan saran, yaitu :

Kerusakan yang terjadi pada beberapa gerbong PPCW 42 ton yang digunakan untuk mengangkut semen, adalah disebabkan karena tingginya tegangan yang terjadi akibat beban operasinya, terutama adalah tegangan amplitudo. Hal ini disebabkan karena perubahan fungsi dari gerbong untuk peti kemas menjadi gerbong pengangkut semen.

Tegangan terbesar terjadi pada saat gerbong beroperasi di jalan berupa tanjakan dan turunan disertai dengan belokan. Sehingga dapat dikatakan bahwa kondisi tersebut merupakan titik kritis terhadap penyebab terjadinya kerusakan.

Agar struktur gerbong aman dioperasikan, dapat dilakukan dengan 2 cara, yaitu struktur gerbong dimodifikasi atau kapasitas beban dikurangi.

Perlu dilakukan kajian lebih lanjut, untuk beberapa topik diantaranya menentukan metode dan model perbaikan dan modifikasi yang optimal, menentukan kapasitas beban yang optimal jika gerbong tidak diperbaiki dan dimodifikasi, menentukan umur lelah dari struktur gerbong jika gerbong tidak dimodifikasi.

\section{DAFTAR PUSTAKA}

1. Standar Tata Cara Pengujian dan Sertifikasi Kelaikan Gerbong, Peraturan Menteri Perhubungan RI No. PM 17 Tahun 2011.

2. Standar Spesifikasi Teknis Gerbong, Peraturan Menteri Perhubungan RI No. KM 43 Tahun 2010.

3. Majalah Kereta Api Indonesia, "Gerbong Datar Multiguna", Juli 2015.

4. Carbon Structural Steel Plate, JIS G 3101, SS 400 Steel, JIS Handbook, Ferrous Materials \& Metalurgy II, 2009.

5. Deicy Corp., "PL-U4610 DR600CTL Instruction Manual", Rev. 1.55, Tokyo, 2013. 
M.I. Mat. Konst. Vol. 16 - Juni 2016 - Hal 1-8

6. Passenger Rolling Stock - Trailer Bogies - Running Gear - Bogie Frame Structure Strength Tests, UIC 515-4, 2003.

7. Bannantine, Julie, A., "Fundamental of Metal Fatigue Analysis", Prentice Hall, Englewood Cliffs, New Jersey, 1990.

8. Daily,J,W, "Experimental Stress Analysis" second edition, Mc Graw Hill, 1978.

9. Deicy Corp., "PL-U4101C1 PcWaveForm Instruction Manual Basic Edition", Rev. 3.05, Tokyo, 2007.

10. Peter C.McKeighan, Narayanaswami Ranganathan, "Fatigue Testing and Analisys under Variable Amplitude Loading", American Society for Testing and Materials International, 2005. 